\title{
Meningitis and Brain Abscess Due to Clostridium Perfringens And Clostridium Paraputrificum Following Orbital Trauma
}

\author{
YVES GIROUARD, GILLES DELAGE, \\ JEAN-PIERRE MATHIEU, and ALBERT LARBRISSEAU
}

\begin{abstract}
SUMMARY: An 8 year old boy developed cerebral abscess and purulent meningitis due to Clostridium perfringens and Clostridium paraputrificum after trauma to the left orbit. The patient made a satisfactory recovery with surgical treatment and antibiotic therapy. A review of the literature revealed that meningitis due to clostridia is rare and usually related to penetrating trauma, and that penetrating trauma to the orbit is associated with significant central nervous system morbidity.
\end{abstract}

RÉSUMÉ: Un garçon de 8 ans a présenté une méningite purulente et un abcès cérébral causés par Clostridium perfringens et Clostridium paraputrificum à la suite d'un traumatisme orbitaire gauche. Le traitement neurochirurgical et l'antibiothérapie ont entraîné une guérison du patient sans séquelles majeures. Une revue de la littérature nous a permis de constater que les méningites clostridiennes sont généralement post-traumatiques, et que les traumatismes pénétrants de l'orbite comportent un taux de complications intracraniennes important.

From the Department of Microbiology and Immunology and the Department of Pediatrics, Université de Montréal, and from the Infectious Diseases Service and the Neurosurgery and Neurology Services, Hôpital Sainte-Justine, Montréal, Québec.

Reprint requests to Dr. Gilles Delage, Département de Microbiologie et Immunologie, Hôpital SainteJustine, 3175, Chemin Sainte-Catherine, Montréal, Québec H3T IC5

\section{INTRODUCTION}

Clostridium perfringens is a rare cause of meningitis or brain abscess. When it does occur, it is usually secondary to penetrating wounds of the central nervous system. Clostridium paraputrificum is even less common and has rarely been implicated in human disease.

In this report we describe an unusual case of a child with purulent meningitis and cerebral abscess in whom both these organisms were isolated.

\section{CASE REPORT}

An 8 year old male caucasian sustained a $1 \mathrm{~cm}$ laceration of the internal portion of the left upper eyelid after being struck with a wooden tent pole. The trauma was considered minor and the wound was sutured. In the ensuing 5 hours, the patient became increasingly drowsy. He complained of headache and neck pain and he vomited four times. He was seen by his physician who noted a fever of $39^{\circ} \mathrm{C}$. The wound was clean and was not draining. Palpation of the wound did not reveal any abnormality and there was no crepitation. There were no signs of meningeal irritation. No specific therapy was given.

The next morning, the child was still drowsy, with periods of agitation. His temperature was $40^{\circ} \mathrm{C}$. Definite signs of meningeal irritation were present and he was admitted to hospital. A spinal tap revealed purulent cerebrospinal fluid (C.S.F.) containing 9920 red blood cells and 4960 polymorphonuclear leucocytes per cubic $\mathrm{mm}$; the glucose level was $78 \mathrm{mg} / \mathrm{dl}$ and the protein content was $98 \mathrm{mg} / \mathrm{dl}$.

Treatment was initiated with $300 \mathrm{mg} /$ $\mathrm{kg} /$ day of ampicillin and $100 \mathrm{mg} / \mathrm{kg} /$ day of chloramphenicol. The next morning, the microbiology laboratory reported the growth of large gram positive rods from the C.S.F. Penicillin at a dose of 200000 units $/ \mathrm{kg} /$ day was substituted for ampicillin. The patient's level of consciousness deteri- orated and paresis of the left lower limb appeared. He was then transferred to Hopital Sainte-Justine.

On arrival the patient was stuporous. $\mathrm{He}$ had a fever of $39^{\circ} \mathrm{C}$, a blood pressure of $110 / 70$ and a pulse rate of $110 /$ minute. The pupils were constricted. Examination of the fundi revealed venous congestion and slight bilateral papilloedema; there was a small retinal hemorrhage close to the left disc. Severe meningismus was present. There were also signs suggesting diffuse involvement of both frontal lobes: a sucking reflex, a rooting response, a bilateral grasp reflex and a palmomental reflex. There was paresis of the left lower limb with increased deep tendon reflexes and a positive Babinski sign on that side. No crepitation of the wound was noted. An area of slight bulging of the sutured wound was incised and a small amount of nonodorous pus was obtained and cultured. Antibiotic therapy was continued; penicillin $G$ was increased to 300,000 units $/ \mathrm{kg}$. Dexamethasone was added.

Computed cranial tomography (CT) done on arrival showed signs of oedema of both frontal lobes (fig. 1). A bone fragment surrounded by air was lodged in the left subfrontal lobe. Tomograms revealed a depressed fracture of the roof of the left orbit; a few bone fragments were found lying $1.5 \mathrm{~cm}$ over the planum.

During the first days of hospitalization, the child remained stuporous. Purposeless automatic motor activity was noted occasionally. By the 10th hospital day, there was marked improvement. The child was awake and able to respond to simple orders although localised weakness of the left leg persisted. A few days later, he began to talk. The wound continued to drain. A repeat CT scan showed extension of cerebral edema into the territory of both anterior cerebral arteries (fig. 2). Bilateral carotid arteriography revealed severe spasm of both these arteries. Air was present in the left frontal horn, and a pneumatocele was noted in the region of the gyrus rectus.

Nineteen days after admission, exploratory craniotomy was performed. A small 


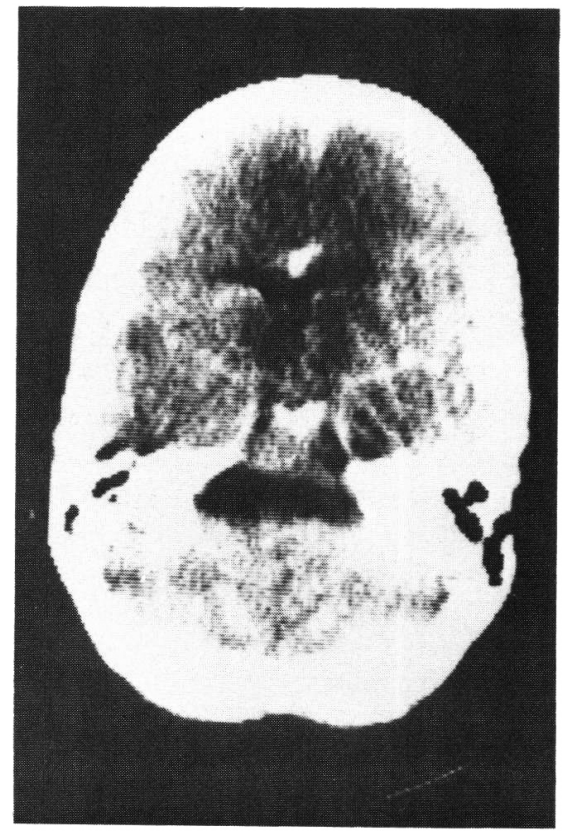

Figure 1-Initial CT scan showing edema of both frontal lobes and a fragment of bone in the left subfrontal area.

brain abscess of the inferior portion of the left frontal lobe was drained. It was noted that this abscess communicated with the ventricular system. Intracerebral bone fragments were removed; duroplasty and reconstruction of the left orbit were performed.

After the operation, the left leg weakness persisted. Behavior was inappropriate and characterised by marked disinhibition. Penicillin was stopped on the 24th day and chloramphenicol on the 34th day of therapy. Another CT scan done during the 8 th week of hospitalization revealed a $1 \mathrm{~cm}$ thick collection of subdural fluid on the left, partial collapse of the lateral ventricle, signs of encephalomalacia of the left subfrontal region and marked atrophy of the right frontal lobe. (fig. 3). Radioisotopic cisternography demonstrated delayed circulation of C.S.F. A subdural-peritoneal shunt was performed using a very low pressure valve of the Hakim type.

At the time of discharge 10 weeks after admission to hospital neurological examination was normal except for slightly hyperkinetic and immature behavior. Two years later he was still hyperkinetic and impulsive, but was attending regular school. The CT scan was normal except for right frontal lobe atrophy.

Microbiology: two strains of strictly anaerobic sporulated gram positive rods were isolated from both the C.S.F. and the wound. They were identified as Clostridium

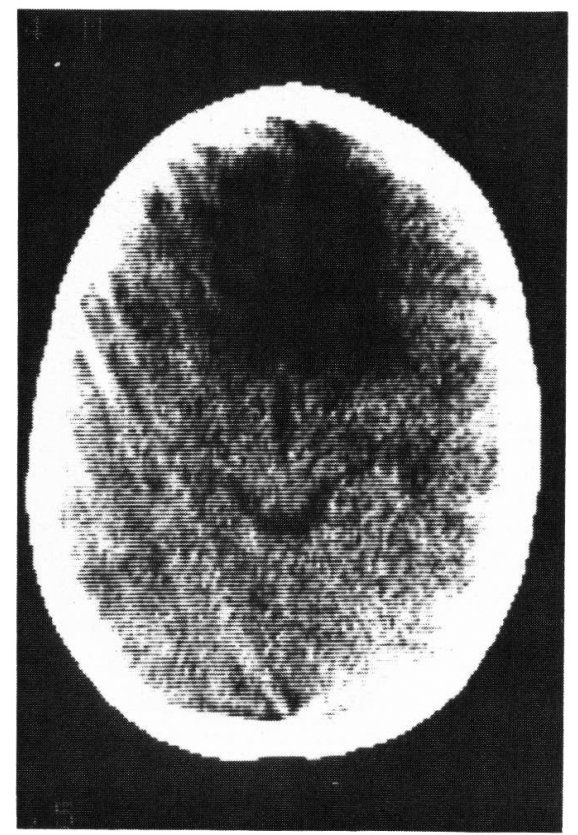

Figure 2-CT scan 2 weeks after admission showing more extensive edema in the territory supplied by both anterior cerebral arteries.

perfringens and Clostridium paraputrificum according to standard methods. The identification of the second organism was confirmed with the use of the API-20A system for identification of anaerobes.

\section{DISCUSSION}

Meningitis due to Clostridium perfringens, with or without brain abscess, is a rare disease. It is most often secondary to severe injuries with penetrating trauma of the central nervous system (Cairns, 1947; Colwell, 1960; Ganchrow, 1971; Grashchenkow, 1945; Henderson, 1945; Moller 1955; Report 1943). Only four cases have been reported following an apparently minor injury. It occasionally complicates craniotomy or laminectomy (Alexander, 1969; Bornstein, 1964; Willis, 1964; Wright, 1966). A few cases have occurred secondary to hematogenous seeding (Conomy, 1969; Gehrz, 1976; Mackay, 1971; Sikorski, 1963). In trauma cases, crepitation suggests the development of gas gangrene and often forecasts a fatal outcome. Cases without crepitation have a much better prognosis. In our patient, the presence of intracerebral air suggested the possibility of

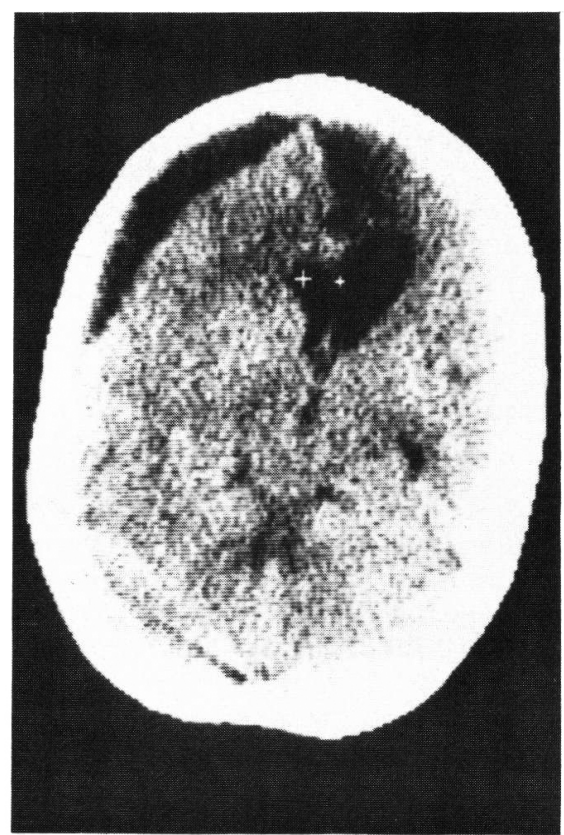

Figure 3-CT scan 8 weeks after admission. Note the collection of subdural fluid on the left and the marked atrophy of the right frontal lobe.

gas gangrene. However the absence of crepitation around the wound and the fact that the patient remained relatively well with an eventual favourable outcome is not compatible with a diagnosis of gas gangrene.

To our knowledge, this is the first case report of meningitis and cerebral abscess in which Clostridium paraputrificum was isolated. This species has rarely been implicated in human disease; it has been related to the presence of gas in the portal vein (Fred, 1968; Wiot, 1961). It was also isolated from the blood of a patient with sepsis due to an infected decubitus ulcer (Rathbun, 1968). This organism is frequently found as a member of the fecal flora of normal individuals; it's role in cancer of the colon is disputed at the present time (Finegold, 1975).

The intracranial complications of penetrating orbital injuries have been well described (Bard, 1964; Duffy, 1969; Dujovny, 1975 Fanning, 1976; Foy, 1980; Guthkelch, 1960; Miller, 1977; Vérin, 1976). These injuries are most common in children. They are usually caused by low velocity missiles and of ten appear to be trivial on initial 
examination. In many cases intracranial penetration is recognized only after the development of neurological complications. Fragility of the orbital roof explains the ease with which foreign bodies can penetrate the intracranial space following such trauma.

The high mobidity and mortality of transorbital injuries (particularly those involving wooden objects) dictate an aggressive approach to the care of these patients (Dujovny, 1975; Miller, 1977). Intracranial penetration must be suspected even if plain skull radiographs are normal. Surgical exploration with removal of retained foreign bodies and bone fragments, and duroplasty is indicated in every case. In our patient there was a 19 day waiting period between admission and surgical removal of the foreign body. The reasons for such a delay were twofold. On admission the neurosurgeon was impressed by the poor state of the patient and the extent of the brain swelling. Therefore, he chose to drain the superficial wound and to observe the clinical course under antibiotic therapy. Thereafter, the gradual improvement of the patient reconfirmed the attending physicians' conviction that conservative therapy was best. Surgery was decided upon after stabilization of the clinical state. We do not recommend that such an approach be taken in all cases of this type. However, in our patient it was dictated by the particular circumstances encountered, among others the delay in diagnosis of the intracranial foreign body and the presence of meningitis. Considering the foregoing facts, the outcome in this case has been unusually good.

\section{REFERENCES}

ALEXANDER, J.G. (1969). A case of fatal Clostridium welchii toxaemia due to ward infection. J. Clin. Pathol. 22: 508.

BARD, L.A. JARRETT, W.H. (1964). Intracranial complications of penetrating orbital injuries. Arch. Ophthal. 71: 332-343.

BORNSTEIN, D.L., WEINBERG, N., SWARTZ, M.N. et al (1964). Anaerobic infections-review of current experience. Medecine (Baltimore) 43: 207-232.

CAIRNS, H., CALVERT, C.A., DANIEL, P., et al (1947). Complications of head wounds with especial reference to infection. Br. J. Surg. (War Surg. Supp. no. 1) I: 198-243.

COLWELL, F.G., SULLIVAN, J., SHUMAN, H.H., et al (1960). Acute purulent meningitis due to Clostridium perfringens. Report of a case. New Engl. J. Med. 262: 618-619.

CONOMY, J.P., DALTON, J.W. (1969). Clostridium perfringens meningitis-Report of a case with neuropathological observations. Arch. Neurol. (Chicago) 21: 44-50.

DUFFY, G.P., BHANDARI, Y.S. (1969). Intracranial complications following transorbital penetrating injuries. Br. J. Surg. 56: 685-688.

DUJOVNY, M., OSGOOD, C.P., MAROON, J.C., et al (1975). Penetrating intracranial foreign bodies in children. J. Trauma 15: 981-986.

FANNING, W.L., WILLETT, L.R., PHILLIPS, C.J., et al (1976). Puncture wound of the eyelid causing brain abscess. J. Trauma 16 : 919-920.

FINEGOLD, S.M., FLORA, D.J., ATTEBERY, H.R., SUTTER, V.L. (1975). Fecal bacteriology of colonic polyp patients and control patients. Cancer Res. 35: 3405-3417.

FOY, P., SHARR, M. (1980). Cerebral abscess in children after pencil-tip injuries. Lancet II: 662-663.

FRED, H.L., MAYHALL, C.G., HARLE, T.S. (1968). Hepatic portal venous gas. A review and report on six new cases. Am. J. Med. 44: 557-565.

GANCHROW, M.I., BRIEF, D.R. (1971). A case of meningitis secondary to Clostridium welchii. J. Trauma 11: 444-446.
GEHRZ, R.C., WARD, R.M., LIEN, R.H. et al. (1976). Meningitis due to combined infections. Association of Haemophilus influenzae type B and Clostridium perfringens. Am. J. Dis. Child. 130: 877-879.

GRASHCHENKOV, N.I. (1945). Anaerobic infection of brain. Am. Rev. Soviet Med. 3: 5-18.

GUTHKELCH, A.N. (1960). Apparently trivial wounds of the eyelid with intracranial damage. Br. Med. J. II: 842-844.

HENDERSON, J.K., KENNEDY, W.F.C., POTTER, J.M. (1954). Recovery from acute Clostridium welchii meningitis. $\mathrm{Br}$. Med. J. II: 1400.

MACKAY, N.N.S., GRUNEBERG, R.N., HARRIES, B.J., THOMAS, P.K. (1971). Primary Clostridium welchii meningitis. Brit. Med. J. 1: 591-592.

MILLER, C.F. II, BRODKEY, J.S., COLOMBI, B.J. (1977). The danger of intracranial wood. Surg. Neurol. 7: 95-103.

MOLLER, B. (1955). Purulent Clostridium welchii meningitis originating from a penetrating wound. Acta Chir. Scand. 109: 394-399.

RATHBUN, H.K. (1968): Clostridial bacteremia without hemolysis. Arch. Intern. Med. 122: 496-501.

REPORT BY COMMITTEE OF SOVIET SCIENTISTS (1943). Gas infection of brain as one form of serious complications of cerebro-cranial injuries. Br. Med. J. I: 785788.

SIKORSKI, J.B., GILROY, J., MEYER, J.S., (1963). Clostridium perfringens (gas bacillus) septicemia and acute purulent meningitis. Harper Hosp. Bull. 21: 38-42.

VÉRIN, PH., VILDY, A., BENJELLOUN, D. (1976). Méningite par traumatisme oculaire. Bull. Soc. Ophtal. Fr. 76: 969-970.

WILLIS, A.T., JACOBS, S.I. (1964). A case of meningitis due to Clostridium welchii. J. Pathol. Bacteriol. 88: 312-314.

WIOT, J.F., FELSON, B., (1961). Gas in the portal venous system. Am. J. Roentgenol. Radium Ther. Nucl. Med. 86: 920-929.

WRIGHT, R.L. Postoperative craniotomy infections. Charles C. Thomas, Springfield, III., 1966. p. 64. 